\title{
Chitosan as Soil Amendment Affects Lettuce Growth, Photochemical Efficiency, and Gas Exchange
}

\author{
Chenping $\mathrm{Xu}^{1}$ and Beiquan Mou
}

ADDITIONAL INDEX WORDS. Lactuca sativa, biostimulant, chlorophyll, photosynthesis

SUMMARY. Chitosan has become of interest as a crop biostimulant suitable for use in sustainable agriculture since it is biocompatible, biodegradable, environmentally friendly, and readily available in large quantity. Short-term (35 d after transplanting) effects of chitosan, applied as a soil amendment at $0 \%, 0.05 \%, 0.10 \%$, $0.15 \%, 0.20 \%$, or $\mathbf{0 . 3 0 \%}(\mathrm{w} / \mathrm{w})$, on lettuce (Lactuca sativa) growth, chlorophyll fluorescence, and gas exchange were evaluated in a growth chamber study. Chitosan at $0.05 \%, 0.10 \%$, and $0.15 \%$ increased leaf area from 674 to 856,847 , and $856 \mathrm{~cm}^{2}$, and leaf fresh weight from 28.6 to $39.4,39.1$, and $39.8 \mathrm{~g}$, respectively. Only chitosan at $0.05 \%$ and $0.10 \%$ increased leaf dry weight from 3.42 to 4.37 and $4.35 \mathrm{~g}$, respectively, while chitosan at $\mathbf{0 . 3 0 \%}$ decreased leaf number, area, fresh and dry weight. Chitosan at $0.10 \%, 0.15 \%, 0.20 \%$, and $0.30 \%$ increased leaf chlorophyll index from 29.8 to $34.4,35.4,37.5$, and 41.4 , respectively. Chitosan at $0.20 \%$ and $0.30 \%$ increased leaf maximum photochemical efficiency and photochemical yield, and chitosan at $0.10 \%, 0.15 \% 0.20 \%$, and $0.30 \%$ increased leaf electron transport rate. Leaf photosynthesis rate and stomatal conductance $\left(g_{\mathrm{s}}\right)$ increased from 9.3 to $12.7,14.0$, and $16.6 \mu \mathrm{mol} \cdot \mathrm{m}^{-2} \cdot \mathrm{s}^{-1}$ carbon dioxide, and from 0.134 to 0.183 , 0.196 , and $0.231 \mathrm{~mol} \cdot \mathrm{m}^{-2} \cdot \mathrm{s}^{-1}$, under chitosan at $0.15 \%, 0.20 \%$, and $0.30 \%$, respectively. The results indicated that chitosan, at appropriate application rates, enhanced lettuce growth, and might have potential to be used for sustainable production of lettuce.

$\mathrm{C}$ hitosan is the deacetylated form of chitin, which is the second most abundant polysaccharide on the planet and the main component of fungal cell walls, insect exoskeletons, and crustacean shells (Gooday, 1990). It was initially reported as an elicitor of plant responses, since it induced phytoalexin (pisatin) production, and as a proteinase inhibitor in plants (Walker-Simmons et al., 1983). Since then, biochemical and molecular responses in plants exposed to chitosan have been investigated and they include increases in cytosolic calcium ion (Zuppini et al., 2003),

U.S. Department of Agriculture, Agricultural Re search Service, U.S. Agricultural Research Station, 1636 East Alisal Street, Salinas, CA 93905

The technical assistance of Phi Diep, and critical review by James McCreight are greatly appreciated.

Mention of trade names or commercial products in this publication is solely for the purpose of providing specific information and does not imply recommendation or endorsement by the U.S. Department of Agriculture.

USDA is an equal opportunity provider and employer.

This research was supported by a grant from the California Department of Food and Agriculture Specialty Crop Block Grant Program (SCB13047).

${ }^{1}$ Corresponding author. E-mail: cpxu1999@hotmail. com.

https://doi.org/10.21273/HORTTECH04032-18 activation of mitogen-activated protein kinases (Yin et al., 2010), oxidative burst (Paulert et al., 2010), callose apposition (Kohle et al., 1985), increase in pathogenesis-related gene mRNA and protein synthesis (Loschke et al., 1983), phytoalexin accumulation and hypersensitive response (Hadwiger and Beckman, 1980), synthesis of jasmonic acid and abscisic acid, and accumulation of hydrogen peroxide (Iriti and Faoro, 2009; Lin et al., 2005). Chitosan has also been extensively studied as a plant protectant to reduce disease incidence and severity in many crops by inhibiting microbial growth and decreasing microbial membrane integrity (Maqbool et al., 2010; Palma-Guerrero et al., 2008; Prapagdee et al., 2007; Xu et al., 2007).
In addition, chitosan has become of interest as a crop biostimulant suitable for use in sustainable agriculture (Pichyangkura and Chadchawan, 2015; Sharp, 2013). Extensive application of synthetic chemicals, such as fertilizers, herbicides and pesticides, to increase crop productivity has been widely practiced to meet food demand around the world. However, they can cause considerable damage to the ecology of agricultural systems and reduce the nutritional quality of crops (Herrick, 2000; Kirschenmann, 2010). Chitosan is biocompatible, biodegradable, environmentally friendly, and readily available in large quantity. It has been reported to improve growth and production of many horticultural crops including vegetable, fruit, and ornamental crops, but in most of those experiments chitosan was foliar applied (El-Miniawy et al., 2013; Farouk and Amany, 2012; Pichyangkura and Chadchawan, 2015; Pirbalouti et al., 2017). Lettuce ( Lactuca sativa) is one of the most important salad vegetables in the United States, and contains important phytochemicals, including vitamins, carotenoids, and other antioxidants (Humphries and Khachik, 2003; Nicolle et al., 2004). The objective of this study was to assess the effects of chitosan as a soil amendment on lettuce growth, chlorophyll fluorescence, and gas exchange.

\section{Materials and methods}

PLANT MATERIALS AND EXPERIMENTS. Two trials, each with four replications, were conducted in a growth chamber, maintained at day/night temperatures of $20 / 15^{\circ} \mathrm{C}$, and a photoperiod of $14 \mathrm{~h}$ with 700 $\mu \mathrm{mol} \cdot \mathrm{m}^{-2} \cdot \mathrm{s}^{-1}$ photosynthetic photon flux $(P P F)$. For each trial, 2 weeks after seeding, uniform lettuce seedlings (cv. Heart's Delight) were transplanted into $1 \mathrm{~L}$ plastic pots filled with $1.2 \mathrm{~kg}$ field soil (sandy loam) mixed with chitosan (Sigma-Aldrich, St. Louis, MO) at $0 \%, 0.05 \%, 0.10 \%, 0.15 \%$,

\begin{tabular}{llll}
\hline $\begin{array}{l}\text { Units } \\
\text { To convert U.S. to SI, } \\
\text { multiply by }\end{array}$ & U.S. unit & SI unit & $\begin{array}{l}\text { To convert SI to U.S., } \\
\text { multiply by }\end{array}$ \\
\hline 0.0929 & $\mathrm{ft}^{2}$ & $\mathrm{~m}^{2}$ & 10.7639 \\
3.7854 & $\mathrm{gal}^{2}$ & $\mathrm{~L}$ & 0.2642 \\
6.4516 & inch & $\mathrm{cm}^{2}$ & 0.1550 \\
0.4536 & $\mathrm{lb}$ & $\mathrm{kg}$ & 2.2046 \\
28.3495 & $\mathrm{OZ}$ & $\mathrm{g}$ & 0.0353 \\
$\left({ }^{\circ} \mathrm{F}-32\right) \div 1.8$ & ${ }^{\circ} \mathrm{F}$ & ${ }^{\circ} \mathrm{C}$ & $\left({ }^{\circ} \mathrm{C} \times 1.8\right)+32$
\end{tabular}


$0.20 \%$, or $0.30 \%$ (w/w), transferred to the growth chamber and watered to capacity with full-strength Hoagland's nutrient solution (Hoagland and Arnon, 1950). The four pots of lettuce for each treatment were watered twice weekly. A complete randomized design was used for each trial in this experiment. Each biological replicate contained one pot with one plant and each treatment included four replicate pots.

GROWTH AND PHYSIOLOGY MEASUREMENTS. For each trial, leaf chlorophyll index was measured at $35 \mathrm{~d}$ after transplanting on the four largest leaves of each plant with a chlorophyll index meter (SPAD-502; Konica Minolta Sensing, Tokyo, Japan). Leaf maximum photochemical efficiency $\left(\mathrm{F}_{\mathrm{v}} / \mathrm{F}_{\mathrm{m}}\right)$, photochemical yield $[\mathrm{Y}(\mathrm{II})]$ and electron transport rate (ETR) were measured with a fluorometer (MINI-PAM-II; Heinz Walz, Effeltrich, Germany) on the four largest leaves of each plant. Leaf $F_{v} / F_{m}$ was measured after leaves were adapted in darkness for $30 \mathrm{~min}$. Leaf net photosynthetic rate $\left\{\mathrm{Pn}\left[\mu \mathrm{mol} \cdot \mathrm{m}^{-2} \cdot \mathrm{s}^{-1}\right.\right.$ carbon dioxide $\left.\left(\mathrm{CO}_{2}\right)\right]$, transpiration $\left\{\operatorname{Tr}\left[\mathrm{mmol} \cdot \mathrm{m}^{-2} \cdot \mathrm{s}^{-1}\right.\right.$ water $\left.\left.\left(\mathrm{H}_{2} \mathrm{O}\right)\right]\right\}$ and gs $\left[\right.$ Cond $\left.\left(\mathrm{mol} \cdot \mathrm{m}^{-2} \cdot \mathrm{s}^{-1}\right)\right]$ were determined on the four largest leaves of each plant using a portable infrared gas analyzer (Li-6400; LI-COR, Lincoln, $\mathrm{NE}$ ). The analyzer was set at a flow rate of $500 \mu \mathrm{mol} \cdot \mathrm{s}^{-1}$, leaf temperature of $20 \pm 0.4{ }^{\circ} \mathrm{C}$, relative humidity of $60 \% \pm$ $5 \%$, with a light emitting diode external light source providing a $P P F$ density of $700 \mu \mathrm{mol} \cdot \mathrm{m}^{-2} \cdot \mathrm{s}^{-1}$. Then plants were harvested to measure leaf number, area, shoot fresh and dry weight (FW and
DW). Leaf area was measured with a leaf area meter (CI-202 laser area meter; CID Bio-Science, Camas, WA). Sample DW was measured after drying at $65^{\circ} \mathrm{C}$ for $3 \mathrm{~d}$.

Statistical analysis. The interaction of the two trials was not significant, so data were pooled together. The mean values of each measured variable in lettuce growth, gas exchange, and chlorophyll fluorescence were separated by Duncan's multiple range test at the 0.05 level of probability using the JMP program (version 5; SAS Institute, Cary, NC) with general linear model. The regression analysis was performed on leaf FW, chlorophyll index, and Pn.

\section{Results and discussion}

Chitosan affected lettuce growth but the responses varied with growth parameters and application rates (Table 1). Chitosan at $0.15 \%$ increased leaf numbers from 12.4 to 13.6 leaves per plant. Leaf area per plant increased from $674 \mathrm{~cm}^{2}$ to 856,847 , and 856 $\mathrm{cm}^{2}$ with chitosan at $0.05 \%, 0.10 \%$, and $0.15 \%$, respectively. Chitosan at $0.05 \%, 0.10 \%, 0.15 \%$, and $0.20 \%$ increased leaf FW from 28.6 to 39.4 , $39.1,39.8$, and $36.2 \mathrm{~g} /$ plant, respectively. Only chitosan at $0.05 \%$ and $0.10 \%$ increased leaf DW from 3.42 to 4.37 and $4.35 \mathrm{~g}$. All chitosan treatments reduced DW/FW ratio. Chitosan at $0.30 \%$ decreased leaf number from 12.4 to 10.9 , area from 674 to $480 \mathrm{~cm}^{2}$, FW from 28.6 to $21.1 \mathrm{~g}$, and DW from 3.42 to $2.27 \mathrm{~g}$. Leaf number, area, FW, and DW showed a quadratic function of application rates (Table 1 ). The quadratic equation for
FW was $y=-680.38 x^{2}+172.35 x+$ 29.672 and $R^{2}$ of 0.6802 (Fig. 1). There was a significant linear effect on leaf chlorophyll index by application rates with an $R^{2}$ of 0.8509 and the equation was $y=37.389 x+30.053$ (Fig. 1). Chitosan at $0.10 \%, 0.15 \%$, $0.20 \%$, and $0.30 \%$ increased leaf chlorophyll index from 29.8 to $34.4,35.4$, 37.5 , and 41.4 .

As a soil amendment, chitosan has been found to enhance plant height, canopy diameter, and leaf area of chili pepper [Capsicum annumm (Chookhongkha et al., 2012)], improve soybean (Glycine max) nodulation and seed yield (Ali et al., 1997), and increase plant height, DW, leaf number and area, and chlorophyll index of tomato (Solanum lycopersicum), rice (Oryza sativa), lettuce, and radish (Raphanus raphanistrum ssp. sativus) (Boonlertnirun et al., 2008; Chibu and Shibayama, 2003; Farouk et al., 2011). Soil-applied chitosan also significantly prompted seedling growth and induced early flowering of many ornamental crops (Pichyangkura and Chadchawan, 2015). Similarly, the present study shows that soil-applied chitosan increased lettuce leaf number, area, FW, DW, and chlorophyll index. The synergetic effects of many factors, such as suppression of plant diseases, insects, and nematodes, increased biomass and activities of beneficial microbes, high nitrogen and calcium content, improved physical structure of soil and nutrient availability, and direct plant growth stimulation, may have resulted from chitosan as a soil amendment.

Table 1. Lettuce leaf growth after $35 \mathrm{~d}$ grown on soil amended with different rates of chitosan. Two-week-old lettuce seedlings were transplanted in 1-L $(0.26 \mathrm{gal})$ plastic pots with soil amended with different rates of chitosan and grown in a growth chamber for $35 \mathrm{~d}$. Pots were irrigated to capacity with full-strength Hoagland's nutrient solution after transplanting and subsequently watered twice weekly.

\begin{tabular}{|c|c|c|c|c|c|c|}
\hline \multirow[b]{2}{*}{ Chitosan rate (\%) } & Leaves (no./plant) & Leaf area $\left(\mathrm{cm}^{2}\right)^{\mathrm{z}}$ & $\mathrm{FW}(\mathrm{g})^{\mathrm{y}}$ & $\mathrm{DW}(\mathrm{g})^{\mathrm{y}}$ & DW/FW (ratio) & Chlorophyll index \\
\hline & \multicolumn{6}{|c|}{ mean \pm SE } \\
\hline 0.00 & $12.4 \pm 0.24 b^{x}$ & $674 \pm 27 b$ & $28.6 \pm 1.62 \mathrm{~b}$ & $3.42 \pm 0.20 \mathrm{~b}$ & $0.120 \pm 0.0012 \mathrm{a}$ & $29.8 \pm 0.47 \mathrm{~d}$ \\
\hline 0.10 & $12.8 \pm 0.37 \mathrm{ab}$ & $847 \pm 17 a$ & $39.1 \pm 1.75 \mathrm{a}$ & $4.35 \pm 0.26 \mathrm{a}$ & $0.111 \pm 0.0017 b$ & $34.4 \pm 0.76 \mathrm{c}$ \\
\hline 0.15 & $13.6 \pm 0.24 \mathrm{a}$ & $856 \pm 34 a$ & $39.8 \pm 2.39 \mathrm{a}$ & $4.10 \pm 0.17 \mathrm{ab}$ & $0.103 \pm 0.0024 \mathrm{c}$ & $35.4 \pm 0.52 b c$ \\
\hline 0.20 & $13.2 \pm 0.37 \mathrm{ab}$ & $781 \pm 50 \mathrm{ab}$ & $36.2 \pm 2.45 \mathrm{a}$ & $3.69 \pm 0.25 \mathrm{ab}$ & $0.102 \pm 0.0017 \mathrm{c}$ & $37.5 \pm 0.81 \mathrm{~b}$ \\
\hline & $0.6144(\mathrm{Q})^{\mathrm{w}}$ & $0.7187(\mathrm{Q})$ & $0.6802(\mathrm{Q})$ & $0.6479(\mathrm{Q})$ & $0.6846(\mathrm{Q})$ & $0.8509(\mathrm{~L})$ \\
\hline
\end{tabular}

${ }^{\mathrm{z}} 1 \mathrm{~cm}^{2}=0.1550$ inch $^{2}$.

${ }^{\mathrm{y}}$ Fresh or dry weight; $\mathrm{l} \mathrm{g}=0.0353 \mathrm{oz}$.

xDifferent letters indicate significant difference at $P \leq 0.05$ according to Duncan's multiple range test.

${ }^{\mathrm{w}} \mathrm{Quadratic}$ or linear. 


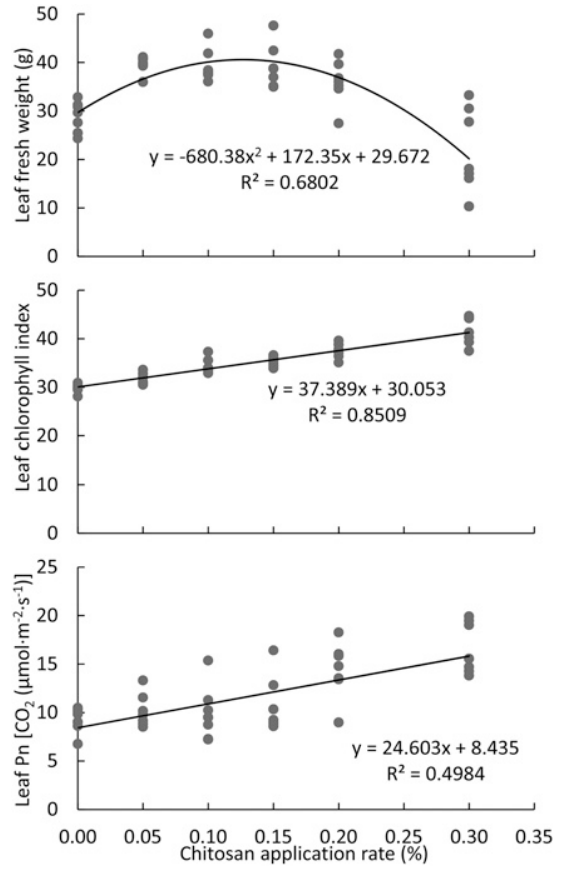

Fig. 1. The responses of lettuce leaf fresh weight, chlorophyll index and photosynthetic rate to chitosan application rate with quadratic or linear curve, regression equation and $R^{2}$ values. Two-week-old lettuce seedlings were transplanted in $1-\mathrm{L}$ $(0.26$ gal $)$ plastic pots with soil amended with different rates of chitosan and grown in a growth chamber for $35 \mathrm{~d}$. Pots were irrigated to capacity with full-strength Hoagland's nutrient solution after transplanting and subsequently watered twice weekly; $\mathbf{P n}=$ net photosynthetic rate, $\mathrm{CO}_{2}=$ carbon dioxide, $1 \mathrm{~cm}^{2}=0.1550 \mathrm{inch}^{2}$, $1 \mathrm{~g}=0.0353 \mathrm{oz}$.

Chitosan as a soil amendment has repeatedly been shown to have strong insecticidal activity, to reduce pathogenic nematode populations, and to control fungal and viral diseases in numerous crops (Aziz et al., 2006; Pospieszny et al., 1991; Rabea et al., 2005; Rodriguez-Kabana et al., 1984). In addition, a substantial body of evidence suggested that the addition of chitosan alters rhizosphere conditions to shift the microbial balance in favor of beneficial organisms and to the detriment of plant pathogens (Sharp, 2013). Chitosan can provide a carbon source for microbes in the soil, accelerate transformation of organic matter into inorganic matter, and assist roots in absorbing more nutrients from the soil (Bolto et al., 2004; Somashekar and Richard, 1996).
Chitosan, and all other chitin derivatives, have a high nitrogen content of $6 \%$ to $9 \%$ (Yen and Mau, 2007), comparable with other organic fertilizers such as dried blood and bone meal (White, 2006). Plants can access the nitrogen in chitin via microbial breakdown and the release of inorganic nitrogen, or by directly taking up monomers as organic nitrogen (Roberts and Jones, 2012; Spiegel et al., 1988). Chitosan can be used to add organic matter to soils without raising the carbon:nitrogen ratio. In addition to nitrogen, chitosan also contains substantial levels of calcium minerals, which provide structural rigidity to the exoskeletons of crustaceans (Boßelmann et al., 2007). Although chitosan contains nitrogen and calcium, its positive effects on crop growth and yield were not only due to its nutrients, since in some studies the nutrients in chitosan were equalized in the control plots treated with inorganic fertilizers. Ohta et al. (2004) and Spiegel et al. (1988) demonstrated that chitosan significantly prompted growth of seedlings of several ornamental plants and chinese cabbage (Brassica rapa ssp. pekinensis), compared with standard mineral fertilizer.

The cationic properties of chitosan also make it suitable as a medium for supplying additional essential nutrients (Sharp, 2013). The functional hydroxyl and amino groups on deacetylated chitosan allow the formation of coordination compounds with ions of copper, zinc, iron, and others, but not with those of alkaline metals (e.g., potassium) or alkaline earth metals (e.g., calcium or magnesium) (Ramírez et al., 2010). This makes chitosan a sustainable alternative to synthetic chelation agents, such as ethylenediaminetetraacetic acid, that are routinely used to deliver iron and other nutrients to overcome their poor solubility in calcareous/neutral soils (Bohn et al., 2002). Due to its high molecular weight and porous structure, chitosan can form gels that absorb substantial volumes of water to increase soil water holding capacity (Jamnongkan and Kaewpirom, 2010; Tamura et al., 2006).

Plant growth stimulation by chitosan as a soil amendment might also result from its direct effect on plant nutrient status and metabolism, and photosynthesis. Soil-applied chitosan increased the content of nitrogen, phosphorus, potassium, total sugars, and soluble proteins as well as total amino acids of radish (Farouk et al., 2011 ). Foliar application of chitosan was reported to increase leaf nitrate reductase activity in indian spinach (Basella alba) and okra (Abelmoschus esculentus) (Mondal et al., 2011, 2012). Soil-applied chitosan has been reported to increase leaf chlorophyll content in many crops (Chibu and Shibayama, 2003; Farouk et al., 2011; Sheikha and Al-Malki, 2011). As a biostimulant, chitosan could also improve chlorophyll fluorescence and increase photosynthetic rate as discussed below.

In this study, application rates had a linear effect on leaf $\mathrm{Fv} / \mathrm{Fm}$, Y(II) and ETR with $R^{2}$ of 0.3427 , 0.2219 , and 0.7311 , respectively ( $\mathrm{Ta}$ ble 2 ). Compared with control, chitosan at $0.20 \%$ and $0.30 \%$ increased leaf $\mathrm{Fv} / \mathrm{Fm}$ from 0.84 to 0.87 and 0.87 , and $\mathrm{Y}(\mathrm{II})$ from 0.359 to 0.503 and 0.497 , respectively (Table 2 ). Chitosan at $0.10 \%, 0.15 \% \quad 0.20 \%$, and $0.30 \%$ increased leaf ETR from 99 to $126,126,159$, and 153 $\mu \mathrm{mol} \cdot \mathrm{m}^{-2} \cdot \mathrm{s}^{-1}$, respectively. Leaf $\mathrm{Pn}$, $\mathscr{I}_{s}$, and $\operatorname{Tr}$ were also linearly affected by application rate with $R^{2}$ of 0.4984 , 0.1595 , and 0.1483 , respectively ( $\mathrm{Ta}$ ble 2$)$. The linear equation for Pn was $y=24.603 x+8.435$ (Fig. 1). Leaf Pn and $g_{s}$ increased from 9.3 to 12.7 , 14.0 , and $16.6 \mu \mathrm{mol} \cdot \mathrm{m}^{-2} \cdot \mathrm{s}^{-1} \quad \mathrm{CO}_{2}$, and from 0.134 to $0.183,0.196$, and $0.231 \mathrm{~mol} \cdot \mathrm{m}^{-2} \cdot \mathrm{s}^{-1}$, under chitosan at $0.15 \%, 0.20 \%$, and $0.30 \%$, respectively (Table 2). Only chitosan at $0.30 \%$ increased leaf $\mathrm{Tr}$ from 3.56 to $5.12 \mathrm{mmol} \cdot \mathrm{m}^{-2} \cdot \mathrm{s}^{-1} \mathrm{H}_{2} \mathrm{O}$. While much research focuses on crop growth, there are very limited reports on leaf chlorophyll fluorescence or gas exchange as affected by soil-applied chitosan. Previous studies indicated that foliarapplied chitosan increased photosynthetic rate in okra and coffee (Coffea canephora) (Mondal et al., 2012; Van et al., 2013). Other studies showed that foliar-applied chitosan reduced $g_{S}$ in pepper and tomato (Bittelli et al., 2001; Lee et al., 1999). The present study suggests that soil-applied chitosan could stimulate crop growth through enhanced photosynthesis resulting from increased chlorophyll content and photochemical efficiency.

In summary, chitosan applied as a soil amendment at an appropriate 
Table 2. Lettuce leaf chlorophyll fluorescence and gas exchange after $35 \mathrm{~d}$ grown on soil amended with different rates of chitosan. Two-week-old lettuce seedlings were transplanted in $1-\mathrm{L}(0.26$ gal $)$ plastic pots with soil amended with different rates of chitosan and grown in a growth chamber for $35 \mathrm{~d}$. Pots were irrigated to capacity with full-strength Hoagland's nutrient solution after transplanting and subsequently watered twice weekly.

\begin{tabular}{|c|c|c|c|c|c|c|}
\hline \multirow[b]{2}{*}{$\begin{array}{l}\text { Chitosan } \\
\text { rate }(\%)\end{array}$} & \multicolumn{3}{|c|}{ Fluorescence measurements $[\text { mean } \pm \mathrm{SE}]^{\mathrm{z}}$} & \multicolumn{3}{|c|}{ Gas exchange $[\text { mean } \pm \mathrm{SE}]^{\mathrm{y}}$} \\
\hline & $\mathrm{Fv} / \mathrm{Fm}$ & $\mathrm{Y}(\mathrm{II})$ & $\begin{array}{c}\text { ETR } \\
\left(\mu \mathrm{mol} \cdot \mathrm{m}^{-2} \cdot \mathrm{s}^{-1}\right)\end{array}$ & $\begin{array}{c}\mathrm{Pn}\left[\mathrm{CO}_{2}\right. \\
\left.\left(\mu \mathrm{mol} \cdot \mathrm{m}^{-2} \cdot \mathrm{s}^{-1}\right)\right]\end{array}$ & $g_{s}\left(\mathrm{~mol} \cdot \mathrm{m}^{-2} \cdot \mathrm{s}^{-1}\right)$ & $\begin{array}{c}\operatorname{Tr}\left[\mathrm{H}_{2} \mathrm{O}\right. \\
\left.\left(\mathrm{mmol} \cdot \mathrm{m}^{-2} \cdot \mathrm{s}^{-1}\right)\right]\end{array}$ \\
\hline 0.00 & $0.84 \pm 0.007 b^{\mathrm{x}}$ & $0.359 \pm 0.0234 \mathrm{c}$ & $99 \pm 2 \mathrm{~d}$ & $9.3 \pm 1.02 \mathrm{c}$ & $0.134 \pm 0.015 \mathrm{c}$ & $3.56 \pm 0.355 b$ \\
\hline 0.05 & $0.86 \pm 0.005 \mathrm{ab}$ & $0.396 \pm 0.0305 \mathrm{c}$ & $105 \pm 6 \mathrm{~cd}$ & $10.2 \pm 0.83 \mathrm{c}$ & $0.132 \pm 0.019 \mathrm{c}$ & $3.38 \pm 0.290 \mathrm{~b}$ \\
\hline 0.10 & $0.85 \pm 0.006 \mathrm{~b}$ & $0.431 \pm 0.0349 \mathrm{bc}$ & $126 \pm 7 \mathrm{bc}$ & $9.9 \pm 1.49 \mathrm{c}$ & $0.145 \pm 0.0327 \mathrm{bc}$ & $3.83 \pm 0.457 \mathrm{~b}$ \\
\hline 0.15 & $0.85 \pm 0.007 \mathrm{ab}$ & $0.429 \pm 0.0339 b c$ & $126 \pm 9 \mathrm{bc}$ & $12.7 \pm 1.45 \mathrm{~b}$ & $0.183 \pm 0.0303 \mathrm{ab}$ & $3.95 \pm 0.592 \mathrm{ab}$ \\
\hline Regression & $<0.001$ & $<0.001$ & $<0.001$ & $<0.001$ & 0.005 & 0.007 \\
\hline & $0.3427(\mathrm{~L})^{\mathrm{w}}$ & $0.2219(\mathrm{~L})$ & $0.7311(\mathrm{~L})$ & $0.4984(\mathrm{~L})$ & $0.1595(\mathrm{~L})$ & $0.1483(\mathrm{~L})$ \\
\hline
\end{tabular}

${ }^{\mathrm{z}} \mathrm{Fv} / \mathrm{Fm}=$ maximum photochemical efficiency, $\mathrm{Y}(\mathrm{II})=$ photochemical yield, ETR $=$ electron transport rate, $1 \mathrm{~m}^{2}=10.7639 \mathrm{ft}^{2}$.

${ }^{\mathrm{y}} \mathrm{Pn}=$ net photosynthetic rate, $\mathrm{CO}_{2}=$ carbon dioxide, $g_{\mathrm{S}}=$ stomatal conductance, $\mathrm{Tr}=$ transpiration rate, $\mathrm{H}_{2} \mathrm{O}=$ water.

${ }^{\mathrm{x}}$ Different letters indicate significant difference at $P \leq 0.05$ according to Duncan's multiple range test.

winear.

rate prompted increased lettuce production, significantly increased leaf number, area, FW, and DW. It also significantly enhanced leaf chlorophyll index and photochemical efficiency, leading to enhanced photosynthetic rate. Our study indicated that chitosan as a soil amendment enhanced lettuce growth and may have potential to be used for the sustainable production of lettuce. However, high rates of chitosan may negatively impact lettuce growth and development. Further investigation is needed to optimize application method, time, and rate for lettuce field production.

\section{Literature cited}

Ali, M., T. Horiuchi, and S. Miyagawa. 1997. Nodulation, nitrogen fixation and growth of soybean plants (Glycine max Merr.) in soil supplemented with chitin or chitosan. J. Jpn. Soc. Hort. Sci. 66:100107.

Aziz, A., P. Trotel-Aziz, L. Dhuicq, P. Jeandet, M. Couderchet, and G. Vernet. 2006. Chitosan oligomers and copper sulphate induce grapevine defense reaction and resistance to grey mould and downy mildew. Phytopathology 96:11881194.

Bittelli, M., M. Flury, G.S. Campbell, and E.J. Nichols. 2001. Reduction of transpiration through foliar application of chitosan. Agr. For. Meteorol. 107:167175.

Boßelmann, F., P. Romano, H. Fabritius, D. Raabe, and M. Epple. 2007. The composition of the exoskeleton of two crustacea: The American lobster Homarus americanus and the edible crab Cancer pagurus. Thermochim. Acta 463:65-68.
Bohn, H.L., R.A. Myer, and G.A. O'Connor. 2002. Soil chemistry. Wiley, Hoboken, NJ.

Bolto, B., D. Dixon, and R. Eldridge. 2004. Ion exchange for the removal of natural organic matter. React. Funct. Polym. 60:171-182.

Boonlertnirun, S., C. Boonraung, and R. Suvanasara. 2008. Application of chitosan in rice production. J. Metals Materials Minerals 18:47-52.

Chibu, H. and H. Shibayama. 2003. Effects of chitosan application on the growth of several crops, p. 235-239. In: T. Uragami, K. Kurita, and T. Fukamizo (eds.). Chitin and chitosan in life science. Kodansha Scientific, Yamaguchi, Japan.

Chookhongkha, N., S. Miyagawa, Y. Jirakiattikul, and S. Photchanachai. 2012. Chili growth and seed productivity as affected by chitosan. Proc. Intl. Conf. Agr. Technol. Food Sci., Manila, Philippines, 17-18 Nov. 2012. p. 146-149.

El-Miniawy, S., M. Ragab, S. Youssef, and A. Metwally. 2013. Response of strawberry plants to foliar spraying of chitosan. Res. J. Agr. Biol. Sci. 9:366-372.

Farouk, S. and A.R. Amany. 2012. Improving growth and yield of cowpea by foliar application of chitosan under water stress. Egypt. J. Biol. 14:14-26.

Farouk, S., A.A. Mosa, A.A. Taha, H.M. Ibrahim, and A.M. El-Gahmery. 2011. Protective effect of humic acid and chitosan on radish (Raphanus sativus L. var. sativus) plants subjected to cadmium stress. J. Stress Physiol. Biochem. 7:99116.

Gooday, G.W. 1990. The ecology of chitin degradation. Adv. Microb. Ecol. 11:387-419.
Hadwiger, L.A. and J.M. Beckman. 1980. Chitosan as a component of pea-Fusarium solani interactions. Plant Physiol. 66:205211.

Herrick, J.E. 2000. Soil quality: An indicator of sustainable land management? Appl. Soil Ecol. 15:75-83.

Hoagland, D.R. and D.I. Arnon. 1950. The water-culture method for growing plants without soil. California Agr. Expt. Sta. Circ. 247.

Humphries, J.M. and F. Khachik. 2003. Distribution of lutein, zeaxanthin, and related geometrical isomers in fruit, vegetables, wheat, and pasta products. J. Agr. Food Chem. 51:1322-1327.

Iriti, M. and F. Faoro. 2009. Chitosan as a MAMP searching for a PRR. Plant Signal. Behav. 4:66-68.

Jamnongkan, T. and S. Kaewpirom. 2010. Potassium release kinetics and water retention of controlled-release fertilizers based on chitosan hydrogels. J. Polymers Environ. 18:413-421.

Kirschenmann, F. 2010. Alternative agriculture in an energy- and resource-depleting future. Renew. Agr. Food Syst. 25:85-89.

Kohle, H., W. Jeblick, F. Poten, W. Blaschek, and H. Kauss. 1985. Chitosanelicited callose synthesis in soybean cells as a $\mathrm{Ca}^{2+}$-dependent process. Plant Physiol. 77:544-551.

Lee, S., H. Choi, S. Suh, I.S. Doo, K.Y. Oh, E.J. Choi, and Y. Lee. 1999. Oligogalacturonic acid and chitosan reduce stomatal aperture by inducing the evolution of reactive oxygen species from guard cells of tomato and Commelina communis. Plant Physiol. 121:147-152.

Lin, W., X. Hu, W. Zhang, W.J. Rogers, and W. Cai. 2005. Hydrogen peroxide 
mediates defence responses induced by chitosans of differ molecular weights in rice. Plant Physiol. 162:937-944.

Loschke, D.C., L.A. Hadwiger, and W. Wagoner. 1983. Comparison of mRNA populations coding for phenylalanine ammonia lyase and other peptides from pea tissue treated with biotic and abiotic phytoalexin inducers. Physiol. Plant Pathol. 23:163-173.

Maqbool, M., A. Ali, P.G. Alderson, and J. Broga. 2010. A combination of gum arabic and chitosan can control anthracnose caused by Colletotrichum musae and enhance the shelf-life of banana fruit. J. Hort. Sci. Biotechnol. 85:432-436.

Mondal, M.M.A., M.I.K. Rana, N.C. Dafader, and M.E. Haque. 2011. Effect of foliar application of chitosan on growth and yield in Indian spinach. J. Agrofor. Environ. 5:99-102.

Mondal, M.M.A., M.A. Malek, A.B. Puteh, M.R. Ismail, M. Ashrafuzzaman, and L. Naher. 2012. Effect of foliar application of chitosan on growth and yield in okra. Austral. J. Crop Sci. 6:918-921.

Nicolle, C., N. Cardinault, E. Gueux, L. Jaffrelo, E. Rock, A. Mazur, P. Amouroux, and C. Rémésy. 2004. Health effect of vegetable-based diet: Lettuce consumption improves cholesterol metabolism and antioxidant status in the rat. Clin. Nutr. 23:605-614.

Ohta, K., S. Morishita, K. Suda, N. Kobayashi, and T. Hosoki. 2004. Effects of chitosan soil mixture treatment in the seedling stage on the growth and flowering of several ornamental plants. J. Jpn. Soc. Hort. Sci. 73:66-68.

Palma-Guerrero, J., H.B. Jansson, J. Salinas, and L.V. Lopez-Llorca. 2008. Effect of chitosan on hyphal growth and spore germination of plant pathogenic and biocontrol fungi. J. Appl. Microbiol. 104:541-553.

Paulert, R., D. Ebbinghaus, C. Urlass, and B.M. Moerschbacher. 2010. Priming of the oxidative burst in rice and wheat cell cultures by ulvan, a polysaccharide from green macroalgae, and enhanced resistance against powdery mildew in wheat and barley plants. Plant Pathol. 59:634642 .

Pichyangkura, R. and S. Chadchawan. 2015. Biostimulant activity of chitosan in horticulture. Scientia Hort. 196:49-65.

Pirbalouti, A.G., F. Malekpoor, A. Salimi, and A. Golparvar. 2017. Exogenous application of chitosan on biochemical and physiological characteristics, phenolic content and antioxidant activity of two species of basil (Ocimum ciliatum and Ocimum basilicum) under reduced irrigation. Scientia Hort. 217:114-122.

Pospieszny, H., S. Chirkov, and J. Atabekov. 1991. Induction of antiviral resistance in plants by chitosan. Plant Sci. 79:63-68.

Prapagdee, B., K. Kotchadat, A. Kumsopa, and N. Visarathanonth. 2007. The role of chitosan in protection of soybean from sudden death syndrome caused by Fusarium solani f. sp. Glycines. Bioresour. Technol. 98:1353-1358.

Rabea, E.I., M.T. El Badawy, T.M. Rogge, C.V. Stevens, M. Höfte, W. Steurbaut, and G. Smagghe. 2005. Insecticidal and fungicidal activity of new synthesized chitosan derivatives. Pest Magt. Sci. 61:951-960.

Ramírez, M.Á., A.T. Rodriguez, L. Alfonso, and C. Peniche. 2010. Chitin and its derivatives as biopolymers with potential agricultural applications. Biotecnologia Aplicada 27:270-276.

Roberts, P. and D.L. Jones. 2012. Microbial and plant uptake of free amino sugars in grassland soils. Soil Biol. Biochem. 49:139-149.

Rodriguez-Kabana, R., G. Morgan-Jones, and B. Ownley-Gintis. 1984. Effects of chitin amendments to soil on Heterodera glycines, microbial populations, and colonization of cysts by fungi. Nematropica 14:10-25.

Sharp, R.G. 2013. A review of the applications of chitin and its derivatives in agriculture to modify plant-microbial interactions and improve crop yields. Agronomy 3:757-793.

Sheikha, S.A. and F.M. Al-Malki. 2011. Growth and chlorophyll responses of bean plants to chitosan applications. European J. Sci. Res. 50:124-134.

Somashekar, D. and J. Richard. 1996. Chitosanase properties and applications: A review. Bioresour. Technol. 55:35-45.

Spiegel, Y., U. Kafkafi, and E. Pressman. 1988. Evaluation of a protein-chitin derivative of crustacean shells as a slowrelease nitrogen fertilizer on Chinese cabbage. J. Hort. Sci. (UK) 63:621-628.

Tamura, H., H. Nagahama, and S. Tokura. 2006. Preparation of chitin hydrogel under mild conditions. Cellulose 13:357-364.

Van, S.N., H.D. Minh, and D.N. Anh. 2013. Study on chitosan nanoparticles on biophysical characteristics and growth of Robusta coffee in green house. Biocatal. Agr. Biotechnol. 2:289-294.

Walker-Simmons, M., L. Hadwiger, and C.A. Ryan. 1983. Chitosans and pecticpolysaccharides both induce the accumulation of the antifungal phytoalexinpisatin in pea pods and antinutrient proteinase inhibitors in tomato leaves. Biochem. Biophys. Res. Commun. 110:194-199.

White, R.E. 2006. Principles and practice of soil science: The soil as a natural resource. 4th ed. Blackwell, Oxford, UK.

Xu, J., X. Zhao, X. Han, and Y. Du. 2007. Antifungal activity of oligochitosan against Phytophthora capsici and other plant pathogenic fungi in vitro. Pestic. Biochem. Physiol. 87:220-228.

Yen, M.T. and J.L. Mau. 2007. Selected physical properties of chitin prepared from shiitake stipes. Food Sci. Technol. 40:558-563.

Yin, H., X. Zhao, X. Bai, and Y. Du. 2010. Molecular cloning and characterization of a Brasica napus L. MAP kinase involved in oligochitosan-induced defense signaling. Plant Mol. Biol. Rpt. 28:2292-2301.

Zuppini, A., B. Baldan, R. Millioni, F. Favaron, L. Navazio, and P. Mariani. 2003. Chitosan induces $\mathrm{Ca}^{2+}$ mediated programmed cell death in soybean cells. New Phytol. 161:557-568. 